\title{
Information Processing Analysis of the Harbor Nautical Charts and Their Representation of the Changes in the Territory: the Case of La Plata Port
}

\author{
Edgardo Stubbs \\ Instituto de Investigaciones en Humanidades y Ciencias Sociales (IdIHCS) FAHCE. UNLP- Conicet. Calle 51 e/ 124 y \\ 125. Edificio C (1925) Ensenada. Buenos Aires. Argentina. \\ Claudia Carut
}

Centro de Investigaciones Geográficas CIG. IdIHCS. FAHCE. UNLP-Conicet. Calle 51 e/ 124 y 125. Edificio C (1925)

Ensenada. Buenos Aires. Argentina.

\begin{abstract}
Nautical charts are a representation of a territorial moment. Understanding the territory as a state of the process of social construction, historical analysis of the nautical charts allows the understanding of the spatial transformations that has crossed a maritime territory. Thus, the study of them represents a tool for the understanding of territorial transformations from the physical-social environment and in their navigation. According to the territory they represent, their scale and the information provided by nautical charts are classified as: general, Sailing, coastal navigation, approach or landfall, and Harbor charts. The latter, which constitute documents that provide important information for different classes of users, are modified as a result of the fact that ports as complex maritime spaces and of great dynamism cause in its coasts and nearby areas important modifications in both the physical and social environment that are reflected in the documents. The information organization and retrieval contained in the nautical charts are essential for access to them. The RDA (Resource for Description and Access) constitute a set of norms for information processing developed from the Librarianship and Information Science. This work will analyze the functionalities of the concepts of work, expression, manifestation and item incorporated to the RDA for the processing of nautical port charts and the possibilities of representation of the changes in the territory that have occurred over time.
\end{abstract}

Keywords: harbor nautical charts - Resource for Description and Access - Functional requirements for Bibliographic Resource - La Plata Harbor - Information Processing - Information retrieval

\section{Introduction}

In each historical moment, we can recognize a production of the territory where objects and actions are constructed and reconstructed and give a new meaning to the territory, with past traces and new imprints that are fruits of the world and the place at the same time. That is, the world events are mixed with the local leaving multiple types of inheritance (Carut, 2014)

To think of territorial organization as a process charged with historicity involves the study of territorial transformations that allow us to unravel these assessments and to understand that this organization of space has historically favored some areas to the detriment of others.

Throughout its history, different assessments of the territory, emerging from the prevailing climate of ideas, manifested in particular logics of appropriation and occupation; construct a succession of vocations, each of which leaves multiple traces (material and / or symbolic): territorial inheritances, in which the past becomes present.

These transformations in the territory described above when represented in different classes of information resources (maps, nautical charts) in the case analyzed, constitute a challenge for those who process this type of information.

According with the Statement of International Cataloguing Principles (IFLA, 2016) establishes 13 general principles as guidelines in the construction of catalogs that allow the retrieval of information. 
Resource Description and Access (RDA) is the accepted international standard for cataloguing resource in the library and Information science discipline. It's was implemented in 2013. This means that although the new standard has been implemented four years ago the process of change and adaptation has not yet been completed. As argued Andrew, Moore and Larsgaard (2014) when learning to describe cartographic resources using the new standard, it will be necessary to do some things differently but other will remain the same as in AACR2, the previous international standard for cataloging bibliographic resources. Part of this process is to learn and understand a new language, or at least new labels that identify objects, ideas and applications.

Focusing our attention on the RDA, it is important to emphasize that they are based on the functional Requirements for Bibliographic Records. These have been developed by IFLA in the 1990s. As stated in the final report of FRBRs the entities that have been defined represent the key objects of interest to users of bibliographic data. The entities have been divided into three groups. The first group comprises the products of intellectual or artistic endeavor that are named or described in bibliographic records: work, expression, manifestation, and item. The second group comprises those entities responsible for the intellectual or artistic content, the physical production and dissemination, or the custodianship of such products: person and corporate body. The third group comprises an additional set of entities that serve as the subjects of intellectual or artistic endeavor: concept, object, event, and place. Each of the entities defined in the model has associated with it a set of characteristics or attributes. The attributes of the entity serve as the means by which users formulate queries and interpret responses when seeking information about a particular entity.

A nautical chart is a graphic representation of a maritime area and adjacent coastal regions. Depending on the scale of the chart, there are different classes of nautical chats: general, Sailing, coastal navigation, approach or landfall, and Harbor. Chart it may show depths of water and heights of land topographic map, natural features of the seabed, details of the coastline, navigational hazards, locations of natural and human-made aids to navigation, information on tides and currents, local details of the Earth's magnetic field, and human-made structures such as harbors, buildings and bridges. Nautical charts are essential tools for marine navigation; many countries require vessels, especially commercial ships, to carry them. Nautical charting may take the form of charts printed on paper or computerized electronic navigational charts. Recent technologies have made available paper charts which are printed "on demand" with cartographic data that has been downloaded to the commercial printing company as recently as the night before printing. With each daily download, critical data such as Local Notice to Mariners is added to the on-demand chart files so that these charts will be up to date at the time of printing.

Nautical charts are based on hydrographic surveys. As surveying is laborious and time-consuming, hydrographic data for many areas of sea may be dated and not always reliable. Depths are measured in a variety of ways. Historically the sounding line was used. In modern times, echo sounding is used for measuring the seabed in the open sea. When measuring the safe depth of water over an entire obstruction, such as a shipwreck, the minimum depth is checked by sweeping the area with a length of horizontal wire. This ensures that difficult to find projections, such as masts, do not present a danger to vessels navigating over the obstruction.

Nautical charts are issued by power of the national hydrographic offices in many countries. These charts are considered "official" in contrast to those made by commercial publishers. Many hydrographic offices provide regular, sometimes weekly, manual updates of their charts through their sales agents. Individual hydrographic offices produce national chart series and international chart series. Coordinated by the International Hydrographic Organization, the international chart series is a worldwide system of charts, which is being developed with the goal of unifying as many chart systems as possible.

There are also commercially published charts, some of which may carry additional information of particular interest, e.g. for yacht skippers.

The objective of the work is focused on the functionalities analysis of the entities defined in the FRBR (work, expression, manifestation and item) incorporated in the RDA for the processing of nautical port charts and the possibilities of representation of changes in the territory which have occurred over time

\section{Origin and evolution of the port of La Plata}

Taking into account these periodization's of the defined economic Azpiazu and Nochteff (1994), the periods of spatial valorization of the metropolitan estuary (Carut, 2014) and the identification of the port organization by Costa (2003) since 
it was put into operation in 1890, it has gone through cycles of boom and decline, in response to these models and their functionality, in general, subordinate to the port of Buenos Aires. can identify four stages:

During the second half of the nineteenth century, Argentina went through a long period of organization towards the constitution of a nation-state based on an external development of the national economy, which would be reflected in port management, with a strong presence of the State in investment (Costa et al., 2003). In addition, it is important to note that, in the case of the ports, the ports are located in the provinces and municipalities (Costa et al., 2003).

As a corollary of the process of national organization, marked by the agro-export development model, in February 1880 , the federalization law of the city of Buenos Aires was issued. This decision arose, and later revived the struggle of interests between the Buenos Aires elites with provincial and national interests. The city of La Plata then emerges as a political project. Not only out of necessity but also as an ideological proposition.

The harbor of La Plata was not part of the architectural contests or the layout of the city made by Burgos and reformulated by the Department of Engineers. The design of the new port of the Ensenada, of 21 feet of draft, was commissioned by Rocha to the Dutch engineer Waldorp in 1882, being approved the plan in 1883.

The territorial configuration designed for the space of the port was based on the idea of continuity between the economy of the Pampas region, based on an agricultural export matrix, materialized in a linear axis that would cross the city (Avenues 51 and 53, monumental axis) and end in port. To the northeast, the axis was directed towards the destination of exported raw materials: Europe; towards the southwest, the axis was imagined internally in the province of Buenos Aires, producing area of these matters (Losano, 2005). As can be seen in the images that accompany the present work, the urban area of La Plata and the port, although contiguous, are separated by the baths of Berisso and Ensenada, low lands and floods that conform the geomorphological unit of the Coastal Plain (Fidalgo and Martínez, 1983; Cavallotto 1995). The differential altimetry of the estuary littoral was valued for the positioning of the city on higher ground in the Continental Plain or Interior Zone (Fidalgo and Martínez 1983), Lomas de Ensenada, and therefore, some $9 \mathrm{~km}$ away from the river.

On March 30, 1890, the Port of La Plata was established. The works had begun in 1883. In just three months, the port access channel had been excavated, and the following year the piling-up was completed, giving shelter to the anteport (Katz, 2007). The Dutch origin of Waldorp - the engineer who developed the project - introduced in the design of the Port the concepts of Dock of Overseas and Dams of Cabotage that still today are evidenced as an indelible mark in the port territory

Until 1896, the economic functioning of the port continued to increase, both in terms of imports and exports, surpassing the latter to the former. Towards 1900 the salt industry began its decline, as the refrigeration industry opened its way.

At the beginning of the 20th century, Paulino Pagani, an Italian who was foreman of port works, settled on the island that later adopted his name, on the left bank of the port channel. There he built a hotel, which during the period of tourism of elites (Bertoncello, 2006), is frequented by personalities from Buenos Aires and Platenses of this social stratum. The lands, belonging first to Lavalle and Medici, and later to the company of the Dock of Transit from 1910, were terraplenados, and during the first half of century XX agricultural activities were developed, being protagonist the production of the denominated wine of the coast.

Meanwhile, Santiago West Island began to be populated by port workers of Italian, Spanish and Uruguayan origins, mainly based on tax lands granted by the state, and gradually developing fruit-horticultural activities (Hernández et al., 2013). The initial vegetation cover of both islands was completely modified by the economic activities therein.

Map 1: Stage prior to the construction of the port La Plata. Period analyzed: 1801-1872

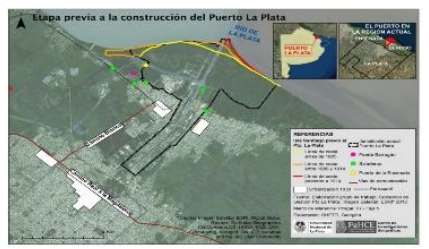


Map 1: Stage prior to the construction of the port La Plata. Period analyzed: 1801-1872. Prepared by: Lic. Georgina Ghetti

\section{A Port in the Service of the Argentine Industry: the Period of Industrialization by Substitution of Imports (1943- 1980)}

The port movement linked to the export of meat products was closely linked to the fluctuations of demand during the world wars. The supply by means of the export of refrigerated meat for the provisions of the armies maintained the boom of the meat industry (Lobato, 1990). However, at the end of the Second World War the demand for meat products exported decreased, and in addition to other factors such as the impossibility of technological readjustment of the refrigerators, the decay of the same began, generating the transformation of the port into one of cabotage

Towards 1940, another great sudestada with a peak of 4,45m, strikes on the coast of the port area affecting seriously the margins of the island Paulino and the activities related to the recreation like the hotel of Pagani and the activities of horticulture and fruit-growing in the island, and whose negative consequences would last for a long time.

Between 1950, and later in 1990 a new process of industrial specialization of the Port is generated and at the same time a decadence of the refrigeration activity begins. Thus, to the Rio Santiago Shipyards (1936), the Textile Cooperative of Labor (1940) is added the Military Factory of Sulfuric Acid (1952) and later Petroquímica Ipako (1962), Propulsora Siderúrgica (1969, of the Techint group, private sector at the mouth of the Arroyo Zanjón on the Santiago River), Petroquímica General Mosconi (1974), Copetro SA (1978), the creation of the Berisso Technological and Information Technology Pole (1989) and the operation since 1990 of an Industrial Estate the port industrial profile. It is, then, an industrial vocation linked, in part, in association with the oil industry. The development of the same will be focused mainly on the Ensenadian margin, unlike the meat industry in the previous period, on the Berisian margin. Parallel to these changes, towards the end of the 1950s, the National State cedes the use of $70 \%$ of the port to the YPF distillery, reaching $90 \%$ the export of the port in fuels (Sanucci, 1983)

Map 2: Model stage industrialization by import substitution

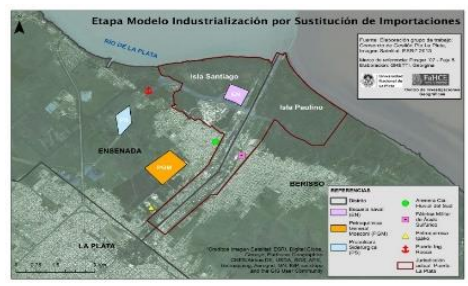

\section{Opening and Decay: the Port in the Economic Opening Model (1980-2001)}

Until 1990, the movement of the port of La Plata was dominated by the YPF and COPETRO Distilleries, which presented deterioration in the access channel. This was compounded by the construction of the Dock Sud pipeline, which acted to the detriment of cargo movement. In 1991, and in the framework of a series of policies of neoliberal cut implemented at national level, Puerto La Plata is transferred to the Province of Buenos Aires (through the decrees of the National Executive Branch 2074/90 and 906/91, ratified by Provincial Law No. 11.206) as part of the state decentralization. It should be clarified that the administration and exploitation of the ports was transferred, although not the ownership of the ports). State policies migrate their role to beneficiaries of private actors, favoring the accumulation of capital of the same.

The return to the provincial level of the jurisdiction of the port of La Plata, made effective with National Law 23.696 / 92 , poses the challenge of a reconfiguration towards the new global market, being one of the first steps the creation of the "Zona Franca La Plata", which was added in 1999, the creation of the Port Management Consortium. The Consortium was constituted as a non-state public entity that has the purpose of administering and operating the Puerto La Plata, with legal, financial, accounting and administrative individuality and dependent on external auditing, through the Court of Auditors and the Organisms of the Constitution of the province of Buenos Aires.

With the aim of modernizing the port structure towards a port suitable for insertion into the global trade dynamics, the Director Plan was formulated, which outlined a series of strategic guidelines for the modernization of the port structure. 
These works included dredging of periodic maintenance, the reconstruction of the southeast breakwater (concreted in the following period, see map 2), the development of terminals of public use specialized in containers.

Map 3: Model stage of economic opening

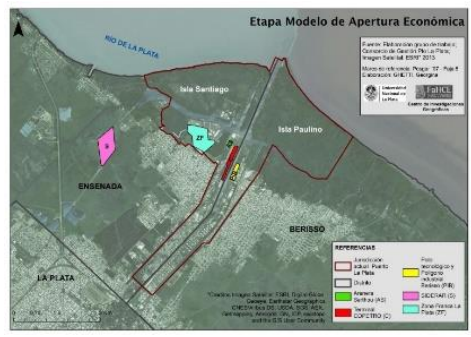

\section{A New Port for the Global Horizons (2001-Today)}

In 2001, under the new Port Master Plan, a public tender was approved for the construction of a Multipurpose Container Terminal.

The ambitious port project includes works in the area of the intermediate and external port to reconvert the profile to a multipurpose port, adding works related to improving road accessibility and service provision. In the first sector, work has been carried out on the expansion of the "Cuatro Bocas" turnaround zone, at the intersection of the port channel with the Santiago River, in order to increase the maneuverability of vessels of $500 \mathrm{~m}$ in diameter, to a depth of 34 feet. In addition, the terminal for the TECPLATA container was completed in 2014, in lands previously belonging to the Armor refrigerator, which is practically in disuse today (see map 2). As complementary works, coastal defenses were carried out on a sector of the intermediate channel and road infrastructure works were started to guarantee connectivity to the metropolitan infrastructure network. Likewise, in 2012, the "Engenada de Barragán" Thermoelectric Power Plant, operated by the state company ENARSA, was launched. The company built a fuel supply facility on Santiago Island (see map 2).

The dredged material of the expansion of "Cuatro Bocas", the deep channeling of the port channel and its mouth, was placed in a sector of the Paulino Island. Although the Consortium declares that it has all the relevant permits, and claims to have carried out the toxicity studies of the retreated sediments, with negative results, complaints have been made by non-governmental

The Master Plan also includes works that have not yet been initiated, such as those relating to the outer port, consisting of a platform that would house terminals of containers, a shopping area, and service area

At the present stage, the port territorial configuration is the result of a mosaic of territorial vocations that refer to different historical pulses, coexisting tourist-recreational in the islands, with military, industrial and services

Map 4: Model Stage of Global Horizons

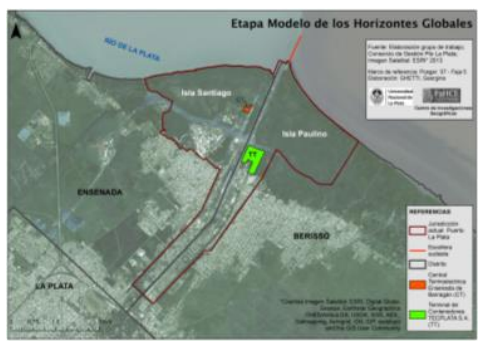

\section{Nautical Chart relevant data}


A nautical chart shows water depth, the shoreline of adjacent land, prominent topographic features, aids to navigation, and other navigational information. It is a work area on which the navigator plots courses, ascertains positions, and views the relationship of the ship to the surrounding area. It assists the navigator in avoiding dangers and arriving safely at his destination.

The data contained in nautical charts can be classified in: general, topographic. Hydrographic and services and aids among the general data it is possible to mention: title blok, that should be the first thing a navigator looks at when receiving a new edition chart. The title itself tells what area the chart covers.

The chart's scale and projection appear below the title. The chart will give both vertical and horizontal datums and, if necessary, a datum conversion note. Source notes or diagrams will list the date of surveys and other charts used in compilation. Shoreline: nautical charts represent the line of contact between the land and water at a selected vertical datum. In areas affected by tidal fluctuations, this is usually the mean high-water line. In confined coastal waters of diminished tidal influence, a mean water level line may be used. If the low water line differs considerably from the high water line, then a dotted line represents the low water line.

If the bottom in this area is composed of mud, sand, gravel or stones, the type of material will be indicated. If the bottom is composed of coral or rock, then the appropriate symbol will be used. The area alternately covered and uncovered may be shown by a tint which is usually a combination of the land and water tint.

Another core elements are the sounding: Charts show soundings in several ways. Numbers denote individual soundings. These numbers may be either vertical or slanting; both may be used on the same chart, distinguishing between data based upon different surveys, different datum, or smaller scale charts. Large block letters at the top and bottom of the chart indicate the unit of measurement used for soundings. Soundings are supplemented by depth contours, lines connecting points of equal depth. These lines present a picture of the bottom. Depths are indicated by soundings or explanatory notes. Only a small percentage of the soundings obtained in a hydrographic survey can be shown on a nautical chart.

Besides these mentioned data, there are others that will not be listed in this work. The analysis will focus on those data to be taken into account when preparing a bibliographic record that have an impact on the retrieval of the information

\section{Harbor nautical chart data and FRBR model}

\section{1) Work, expression, manifestation and item}

A work is an abstract entity; there is no single material object one can point to as the work. We recognize the work through individual realizations or expressions of the work, but the work itself exists only in the commonality of content between and among the various expressions of the work. The attributes of a work for that are unique to harbor nautical charts is:

Coordinates: Degrees, minutes and seconds of longitudes and latitudes

An expression is the intellectual or artistic realization of a work in the form of alpha-numeric, musical, or choreographic notation, sound, image, object, movement, etc., or any combination of such forms. Defining expression as an entity in the model gives us a means of reflecting the distinctions in intellectual or artistic content that may exist between one realization and another of the same work. The attributes of a work for that are unique to harbor nautical charts are:

Scale: Scale is the ratio of distances in a cartographic expression to the actual distances they represent.

Projection: is the method or system used to represent the surface of the Earth or of a celestial sphere on a plane

Presentation Technique: is the method used to represent geographic or other features in a cartographic image

Representation of relief: is the technique used to depict the elevations or the inequalities of a land surface or of the bed of a body of water in a cartographic image

Geodetic, Grid, and Vertical Measurement: information on the spheroid used to construct the cartographic image, the grid or referencing systems used in the image, horizontal datum, vertical datum, mathematical data on contour intervals, bathymetric intervals, etc. 
Recording Technique: is the technique used to capture an image through remote sensing (e.g., multispectral photography, infrared line scanning, SLAR, passive microwave mapping, etc.).

Special Characteristic: A special characteristic of a remote sensing image or an image produced through aerial photography is the altitude and attitude of the sensor, the position of the platform, the category and name of the satellite, the number of spectral bands involved, the quality of the image, the extent of cloud cover, or the mean value of the ground resolution

The manifestation is the physical embodiment of an expression of a work. The entity defined as manifestation encompasses a wide range of materials, including manuscripts, books, periodicals, maps, posters, sound recordings, films, video recordings, CD-ROMs, multimedia kits, etc. As an entity, manifestation represents all the physical objects that bear the same characteristics, in respect to both intellectual content and physical form

There's not specific attributes for nautical chart at this level. the general attributes that also apply to nautical charts are

Title of the Manifestation, Statement of Responsibility, Edition/lssue Designation, Place of Publication/Distribution, Publisher/Distributor, Date of Publication/Distribution, Fabricator/Manufacturer, Series Statement, Form of Carrier, Extent of the Carrier, Physical Medium, Capture mode, Dimensions of the Carrier, Manifestation Identifier, Source for Acquisition/Access Authorization, Terms of Availability, Access Restrictions on the Manifestation.

The entity defined as item is a concrete entity. It is in many instances a single physical object (e.g., a copy of a one-volume monograph, a single Nautical chart, etc.). There are instances, however, where the entity defined as item comprises more than one physical object (e.g., a monograph issued as two separately bound volumes, a recording issued on three separate compact discs, etc.).

In terms of intellectual content and physical form, an item exemplifying a manifestation is normally the same as the manifestation itself. However, variations may occur from one item to another, even when the items exemplify the same manifestation, where those variations are the result of actions external to the intent of the producer of the manifestation (e.g., damage occurring after the item was produced, binding performed by a library, etc.).

The attributes of an item defined for the FRBR are the following: item identifier, fingerprint, provenance of the item, marks/inscriptions, exhibition history, condition of the item, treatment history, scheduled treatment, access restrictions on the item

\section{2) Person and corporate body}

Persons are treated as entities only to the extent that they are involved in the creation or realization of a work (e.g., as authors, composers, artists, editors, translators, directors, performers, etc.), or are the subject of a work (e.g., as the subject of a biographical or autobiographical work, of a history, etc.).

The attributes for a person defined for the model are: name of person, dates of person, title of person, other designation associated with the person

Corporate body is an organization or group of individuals and/or organizations acting as a unit.

The entity defined as corporate body encompasses organizations and groups of individuals and/or organizations that are identified by a particular name, including occasional groups and groups that are constituted as meetings, conferences, congresses, expeditions, exhibitions, festivals, fairs, etc. The entity also encompasses organizations that act as territorial authorities, exercising or claiming to exercise government functions over a certain territory, such as a federation, a state, a region, a local municipality, etc.

The attributes for a corporate body defined for the model are: name of the corporate body, number associated with the corporate body, place associated with the corporate body, date associated with the corporate body, other designation associated with the corporate body

\section{3) Concept, object, event and place}

The entity defined as concept encompasses a comprehensive range of abstractions that may be the subject of a work: fields of knowledge, disciplines, schools of thought (philosophies, religions, political ideologies, etc.), theories, processes, techniques, practices, etc. A concept may be broad in nature or narrowly defined and precise. 
The attribute defined for a concept is: term for the concept

The entity defined as object encompasses a comprehensive range of material things that may be the subject of a work: animate and inanimate objects occurring in nature; fixed, movable, and moving objects that are the product of human creation; objects that no longer exist.

The attribute defined for a object is: term of the object

The entity defined as a event encompasses a comprehensive range of actions and occurrences that may be the subject of a work: historical events, epochs, periods of time, etc.

The attribute defined for an event is: term for the event

The entity defined as a place encompasses a comprehensive range of locations: terrestrial and extra-terrestrial; historical and contemporary; geographic features and geo-political jurisdictions.

The attribute defined for a place is: term for the place

it should be noted that the entities of the third group (concept, object, event and place) are not defined for the RDA, so they will not be considered for the present analysis.

\section{Application of the RDA for the processing of nautical charts of ports: the case of the Port of La Plata}

As has been discussed in previous paragraphs, the territory involved in the area of the Port of La Plata has undergone successive changes over the last 100 years. The making of documents as nautical charts over time represents these changes that translate into important information for the user.

How does the RDA cataloging code of recent implementation respond to these information needs? Analyzing the FRBR model and its application in the RDA code on the one hand, there are no changes in the data that allow us to describe the port nautical charts. The following table shows the above mentioned

Nevertheless the concepts of work, expression, manifestation and item allow to link the different documents of the same place through time. The port of La Plata has gone through four clearly differentiated stages that are manifested through different documents. Each document (maps or nautical charts of the port of La Plata) represents a distinct stage with a given space structure. Each map represents different moments of the same work, with four different expressions, each of which contains its manifestation, with its item.

\section{Conclusion}

This conceptual model for information processing allows establishing links between information resources that have a common origin. This functionality of the FRBR applied to resources such as nautical charts of ports generates a benefit to the user when retrieving related information optimizing their time and reducing the dispersion of information

The application of this model to the processing of this type of resources endows the register of meaning by transforming the data into elements relevant to the description, allowing the distinction between entities such as work, expression, manifestation and item.

It is important to emphasize that the bibliographic description includes elements of the manifestation and also attributes that link it with the expression and the work

It is important to emphasize that this functionality of the bibliographic record improves the information retrieval process, but also allows the user to have additional elements of information resource selection and the possibility of navigating through the catalog

\section{Bibliography}

[1] American Library Association, Chartered Institute for Librarian and Information Professionals, Canadian Federation of Library Association.. Resource and Description for Access RDA (2016). Retrieved from http://www.rdatoolkit.org/

[2] Andrew PG, Moore SM and Larsgaard M (2014) RDA and cartographic resources. London: Facet. 144 p. 
[3] Azpiazu D, Nochteff H. (1994). El desarrollo ausente. Buenos Aires: Norma

[4] Barone, M. (2016). Los puertos en la provincia de Buenos Aires a 20 años de la provincialización. Anales De La Facultad De Ciencias Jurídicas Y Sociales, Universidad Nacional De La Plata, 13 (46) 304-318.

[5] Bertoncello, R. (2006). Turismo, territorio y sociedad: el mapa turístico de la Argentina. América Latina: cidade, campo e turismo A. Geraiges de Lemos, M. Arroyo \& M. Silveira, San Pablo: CLACSO.

[6] Carut, C. (2014). La metropolización costera de la Región Metropolitana de Buenos Aires : Un juego dialéctico de los lugares : Entre la inserción y su aislamiento en la nueva metropolización de la década de los 90 (Tesis Doctoral). Universidad Nacional de La Plata. Facultad de Humanidades y Ciencias de la Educación, La PLata

[7] Cavallotto JL (1995) Evolución geomorfológica de la llanura costera del margen sur del Río de la Plata. Tesis Doctoral Facultad de Ciencias Naturales y Museo, UNLP. La Plata

[8] Costa, A., Brieva, S., Iriarte, L. (2003). Gestión y Regulación de los servicios e infraestructura portuaria en Argentina. Problemas del Desarrollo. Revista Latinoamericana De Economía, 34 (135) 29-47

[9] Fidalgo, F., \& Martinez, O. (1983). Algunas características geomorfológicas dentro del Partido de La Plata (Buenos Aires). Revista De La Asociación Geológica Argentina, 38, 263-279.

[10] Hernández, M., Novoa, S., Civitella, D., Masón, D., \& Oviedo, A. (2013). Plantas usadas en medicina popular en la Isla Santiago, Buenos Aires, Argentina. Bol. Latinoam. Caribe Plant. Med. Aromát., 12, 385-399.

[11] IFLA (2016) Declaración de principios internacionales de catalogación. Retrieved from: https://www.ifla.org/files/assets/cataloguing/icp/icp_2016-es.pdf

[12] Katz, R. (2007). Ciudad de La Plata: su historia. Author's Edition.

[13] Lobato, M. (1990). Mujeres en la fábrica. El caso de las obreras del frigorífico Armour, 1915-1969. Anuario Del Instituto De Estudios Histórico Sociales, 171-205. Losano, G. (2006). La Plata: de la ciudad apreciada a la ciudad ignorada. Geograficando, 2(2). Retrieved from http://www.fuentesmemoria.fahce.unlp.edu.ar/art_revistas/pr.360/pr.360.pdf

[14] Sanucci, L. (1983). Berisso, un reflejo de la evolución argentina. Municipalidad de Berisso 